\title{
AUDIT
}

\section{Clinical presentation of acute chest syndrome in sickle cell disease}

C Taylor, F Carter, J Poulose, S Rolle, S Babu, S Crichlow

Postgrad Med J 2004;80:346-349. doi: 10.1136/pgmj.2003.012781

In this study the records of 45 patients with sickle cell disease involved in 63 presentations of acute chest syndrome at the Princess Margaret Hospital in Nassau, the Bahamas, between 1997 and 2001 were examined. Patients were divided into three groups on the basis of age $(<13$ years, $13-18$ years, $\geqslant 19$ years) with a view to assessing clinical presentation. The incidence of symptoms, physical signs, and laboratory findings were enumerated and significant differences between age groups determined. The data were analysed using analysis of variance, $t$ test, and $\chi^{2}$ test and compared with existing knowledge on the subject.

This study proposed to evaluate the clinical presentation of acute chest syndrome with emphasis on historical and physical findings, and to encourage the physician to maintain a high index of suspicion for the condition in susceptible patients. It was found that presentation varied significantly with age groups, children presenting most classically with fever and cough and adults, with chest pain. The 13-18 age group emerged as the group which presented most frequently with the typical symptoms of chest infection, thus potentially making diagnosis easier. Of note, the most frequent finding was a normal examination, while the second commonest physical finding was crepitations on auscultation of the chest.

See end of article for authors' affiliations

Correspondence to Dr C Taylor, Derriford Hospital, Plymouth, Devon PL6 8DH, UK;

charlesy7@hotmail.com

Submitted 18 July 2003 Accepted

15 September 2003
$\mathrm{T}$ he diagnosis of acute chest syndrome (ACS) in sickle cell disease represents an important challenge to the physician. It may present insidiously and non-specifically, often complicating other conditions. It is, however, imperative that we correctly identify and aggressively treat this condition as it is the major cause of mortality in sickle cell disease, accounting for $25 \%$ of deaths and occurring across all age ranges. ${ }^{12}$ This syndrome has been well documented to be multifactorial in nature with underlying factors including fat embolism, infection with a wide range of organisms, and infarction. The greatest concern is the elusiveness of the significant number of patients that may have a normal or slightly abnormal examination on presentation but are at no less risk of significant disease. ${ }^{3}$ In this study we hope to add to the understanding of, and sensitise physicians to, the spectrum of the clinical presentation of this syndrome.

\section{METHODS}

A retrospective cohort study during a five year period beginning January 1997 and ending December 2001 was done. The records of all patients with sickle cell disease who were admitted to the Princess Margaret Hospital, Nassau, in the Bahamas, during the period specified by the study were carefully perused. Those admitted to the study fulfilled two criteria: (i) lower respiratory tract symptoms and (ii) new pulmonary infiltrates on the chest radiograph.

This is in keeping with the most widely accepted definition of ACS. Historical, clinical, and laboratory data were obtained and analysed with a view to determining common modes of presentation and assessing whether these differed between age groups. Sixty three cases of ACS involving 45 patients were found. Analysis of variance and $t$ test were used to assess means and the $\chi^{2}$ test was used to assess statistical differences between groups. The groups compared were $<13$ years, $13-18$ years, and $\geqslant 19$ years.

\section{RESULTS}

\section{Profile of patients}

All of the patients were Afro-Caribbean. The patients' ages ranged from 1-37 years with 46\% of cases under 13 years (mean 15.6, median 15 years). Altogether $62 \%$ of the cases were female and $38 \%$ were male. The number of admissions for each patient ranged from one to four.

\section{Reason for admission}

The admitting diagnosis in $79 \%$ of the cases was ACS, while the remaining $21 \%$ were admitted for vaso-occlusive crises (most common) and surgical procedures but subsequently developed ACS during their hospital stay.

\section{Presenting symptoms}

The most common presenting symptoms were cough, fever, and chest pain respectively. The frequency of presenting symptoms was dependent on the age of the patient (fig 1). In children younger than 13 years fever and cough were the two commonest symptoms while in those older than 13 years, cough and chest pain were more frequent. Those aged 13-18 years were more likely to present with sputum production than those in the other age groups. Statistically significant differences were observed for the presenting symptoms fever $(p=0.020)$, shortness of breath $(\mathrm{p}=0.045)$, and sputum production

Abbreviations: ACS, acute chest syndrome; LOS, length of stay 


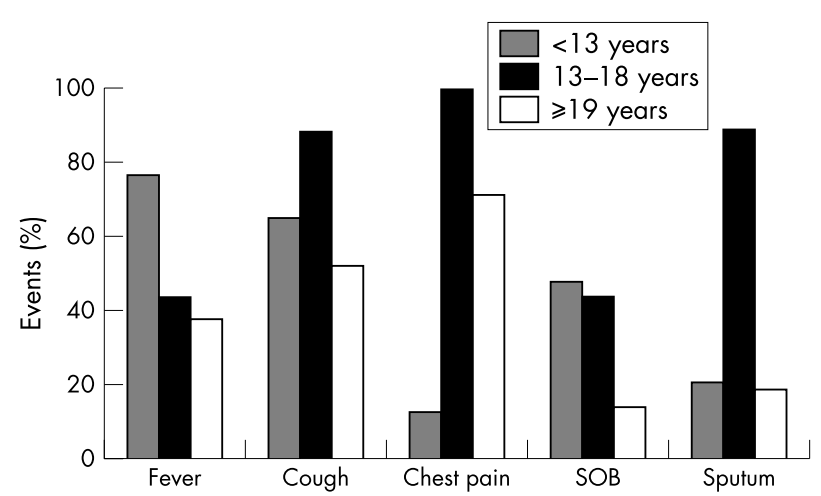

Figure 1 Percent of events with selected symptoms by age group $(n=63)$ (SOB, shortness of breath).

$(\mathrm{p}<0.005)$ when the age groups were compared. None of the patients reported haemoptysis or wheeze.

\section{Physical findings}

Vital signs on presentation were shown to be age dependent with children presenting with higher temperature, respiratory rate $(\mathrm{p}=0.004)$, and pulse rate $(\mathrm{p}<0.005)$ than adults. The average temperature in children under 13 years of age was $37.3^{\circ} \mathrm{C}$, while that for teenagers was $36.8^{\circ} \mathrm{C}$ and for adults $37.0^{\circ} \mathrm{C}$ (see other examination variables in table 1 ). The most common physical finding was a normal examination $(36.7 \%)$, crepitations on lung auscultation being the second most common finding (fig 2).

\section{Laboratory findings}

The level of platelets on admission was lower in the $<13$ age group $(p=0.01)$ but there were no other statistically significant differences between age groups (table 2 ).

The mean (SD) haemoglobin concentration (in $\mathrm{g} / \mathrm{l}$ ) was 78.6 (1.4), 87.3 (12.6), and 88.1 (19.3) in the $<13,13-18$, and $\geqslant 19$ age groups respectively; white cell count was higher in the $<13$ and $13-18$ age groups.

\section{Hospital course}

The average length of stay (LOS) was 10 days (range 335 days) with $60 \%$ of patients staying more than eight days. Male patients on average were hospitalised longer than their female counterparts (mean LOS male 11.4 days and female LOS 9.7 days). Five patients died giving an in-hospital mortality rate of $7.9 \%$.

\section{DISCUSSION}

ACS can be defined as the occurrence of lower respiratory tract symptoms in combination with new pulmonary infiltrates on chest radiography, in a patient with sickle cell disease.

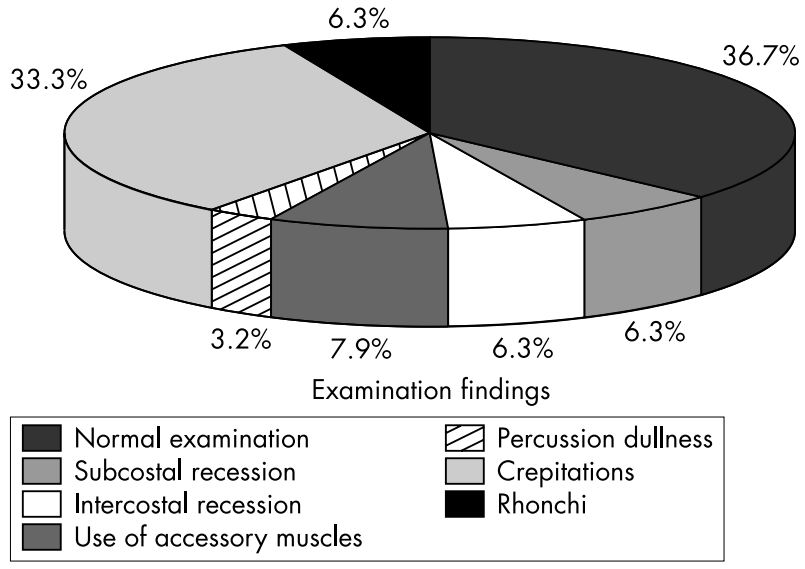

Figure 2 Findings on physical examination as a percentage of total study group $(n=63)$.

It has long been known that this syndrome is a multifactorial process with the likely final common pathway being in situ microvascular thrombosis. Great light was shed on the relative weighting of the possible aetiological factors by Vichinsky et al. ${ }^{4}$ In the largest series of its kind 671 episodes of ACS in 538 patients were evaluated extensively to identify possible aetiological factors. In this series Vichinsky reported no identifiable cause in $45.7 \%$ of cases, infection was documented in $29.4 \%$ of cases (with only $15 \%$ of infection being cased by typical bacteria), infarction occurred in $16.1 \%$, and fat embolisation in $8.8 \%$. The clinical presentation of ACS is linked to the dominant aetiological factor so it is not at all surprising that a wide spectrum is seen.

The paediatric presentation in this series was consistent with previous trends, ${ }^{367}$ with fever, cough, and shortness of breath being the predominant symptoms. Additionally, our finding of increased temperature, pulse rate, and respiratory rate in children was consistent with the cooperative study. ${ }^{3}$ Early studies showed a high percentage of proven bacterial infection in children ${ }^{8}$; this was, however, before the wide spread use of pneumococcal vaccine and penicillin prophylaxis. Interestingly more recent studies show the same clinical pattern but with most cases being culture negative; this may represent an increased relative role of atypical bacterial and viral infections in children. Sputum production was significantly higher in the 13-18 year age group $(\mathrm{p}<0.001)$. In the Cooperative Study of Sickle Cell Disease, ${ }^{3}$ which was the largest series on clinical presentation of ACS, sputum production was shown to progressively increase with age from the $<2$ to the $>20$ year age groups, in contrast to what was seen in our study.

Of considerable interest, we found that the age group 1318 years presented with the greatest number of symptoms consistently, potentially making them the easiest to diagnose on clinical grounds (see fig 1) with cough, chest pain, and

\begin{tabular}{|c|c|c|c|}
\hline Examination & $\begin{array}{l}<13 \text { years } \\
(n=29)\end{array}$ & $\begin{array}{l}13-18 \text { years } \\
(n=9)\end{array}$ & $\begin{array}{l}\geqslant 19 \text { years } \\
(n=25)\end{array}$ \\
\hline Pulse rate $/ \mathrm{min}^{*}(p<0.00005)$ & $119.54(20.17)$ & $95.78(22.55)$ & $87.32(13.88)$ \\
\hline Respiratory rate $/ \mathrm{min}^{*}(p=0.004)$ & $32.07(10.59)$ & $26.67(11.87)$ & $22.44(3.11)$ \\
\hline $\begin{array}{l}\text { Systolic pressure }(\mathrm{mm} \mathrm{Hg})^{*} \\
(p=0.024)\end{array}$ & $94.33(35.22)$ & 109.78 (9.38) & $124.21(22.78)$ \\
\hline $\begin{array}{l}\text { Diastolic pressure }(\mathrm{mm} \mathrm{Hg})^{*} \\
(p=0.084)\end{array}$ & $54.17(22.96)$ & $61.89(6.77)$ & 69.11 (13.71) \\
\hline
\end{tabular}


Table 2 Investigation by age group $(n=63)$; values are mean (SD)

\begin{tabular}{llll}
\hline Investigation & $\begin{array}{l}<13 \text { years } \\
(\mathbf{n}=29)\end{array}$ & $\begin{array}{l}13-18 \text { years } \\
(\mathbf{n}=9)\end{array}$ & $\begin{array}{l}\geqslant 19 \text { years } \\
(\mathbf{n}=\mathbf{2 5})\end{array}$ \\
\hline Haemoglobin $(\mathrm{g} / \mathrm{l})(\mathrm{p}=0.107)$ & $78.6(14.0)$ & $87.3(12.6)$ & $88.1(19.3)$ \\
Packed cell volume $(\mathrm{p}=0.063)$ & $0.23(0.04)$ & $0.26(0.04)$ & $0.26(0.06)$ \\
Platelets $\times 10^{9} / \mathrm{I}^{*}(\mathrm{p}=0.010)$ & $296.25(136.30)$ & $440.17(199.06)$ & $426.10(138.09)$ \\
White cell count $\times 10^{9} / \mathrm{I}(\mathrm{p}=0.062)$ & $23.11(14.62)$ & $28.90(23.32)$ & $16.16(5.41)$ \\
Urea $(\mathrm{mmol} / \mathrm{l})(\mathrm{p}=0.610)$ & $10.6(11.19)$ & $8.75(2.55)$ & $8.32(2.91)$ \\
Creatinine $(\mu \mathrm{mol} / \mathrm{l})(\mathrm{p}=0.187)$ & $0.51(0.33)$ & $0.50(0.18)$ & $0.65(0.18)$ \\
\hline
\end{tabular}

*Statistically significant differences exist for these variables (analysis of variance $p<0.05$ ).

sputum production being nearly always present. The other two age groups had far less consistent clinical findings.

Clinical examination is potentially the most misleading aspect of assessment of this syndrome. The Cooperative Study of Sickle Cell Disease ${ }^{3}$ found that the second most common examination finding was a normal examination, representing $35 \%$ of cases. In contrast, Agtmael et al in an analysis of 81 episodes in 53 Afro-Caribbean patients documented abnormal examinations in at least $91 \% .^{10}$ In our series $36.7 \%$ had a normal examination, the commonest finding. This is a feature we wish to highlight as it can lead the unwary doctor to assume that less aggressive management is warranted when in fact, clinically there are no good predictors of which patients may succumb. ${ }^{3}$

Genotype analysis was not included in this study as it has been clearly and repeatedly shown that clinical presentation is independent of genotype, ${ }^{39}$ although HbSS and HbS $\beta$ thalassaemia patients may have more frequent episodes. ${ }^{11}{ }^{12}$ The small number of events evaluated and its retrospective design limit this study. Arterial blood gas analysis was not included, as consistent information on its relationship to oxygen supplementation was not available and blood

\section{Known and proposed causes of ACS}

- Infection:

- Bacterial infection.

- Atypical bacterial pneumonia.

- Viral pneumonia.

- Parvovirus B19.

- Pulmonary vascular occlusion:

- In situ pulmonary thrombosis.

- Fat embolism.

- Peripheral thromboembolism.

- Hypoventilation/atelectasis:

- Thoracic bony infarction.

- Abdominal pain.

- Opioids.

- Pulmonary oedema:

- Intravenous fluids.

- Opioids.

- Pulmonary vascular injury.

- Other:

- Bronchospasm.

(Adapted from Quinn and Buchanan 5 ) cultures were not uniformly taken, making it impossible to draw conclusions on the range of causative organisms. For this reason as well, it was not possible to ascertain which mechanism (pathologically) was responsible for the cases of ACS encountered. We also acknowledge that there may be some interobserver variation with respect to the presence or absence of critical clinical signs but we believe this to be an inherent part of any study of this nature and must always be borne in mind.

In summary, one of the most important aspects of management of ACS is early diagnosis. However symptoms can vary widely and examination is frequently non-contributory. Teenagers may represent the age group in which there is the greatest number of symptoms but even in the absence of classical signs a high index of suspicion should be maintained. The most sensitive definition of this syndrome is lower respiratory tract symptoms in the presence of new pulmonary infiltrates in a patient with sickle cell disease, which will include the patient who is apyrexial and has a normal examination. It must be appreciated that this syndrome frequently complicates unrelated hospital admissions (for example, in half of patients, ACS is preceded by vaso-occlusive crises $^{13}$ and in our study it was $21 \%$ ), and should be actively sought out with each inpatient review so that early management can be instituted and morbidity and mortality limited.

Absence of pyrexia or, indeed, a normal examination at presentation, does not exclude the diagnosis.

\section{ACKNOWLEDGEMENTS}

The authors would like to thank Dr P Gomez, Chief of Internal Medicine and Infectious Diseases, Princess Margaret Hospital, Bahamas; Dr SinQuee, Consultant in Paediatrics, Princess Margaret Hospital, Bahamas; Mr T Fountain, Health and Research Unit, Ministry of Health, Bahamas; and Dr M Hamon, Consultant in Haematology, Derriford Hospital, Plymouth, UK.

\section{Authors' affiliations}

C Taylor, F Carter, J Poulose, S Rolle, S Babu, S Crichlow, Derriford Hospital, Plymouth, Devon, UK

\section{REFERENCES}

1 Thomas AN, Pattison C, Serjeant GR. Causes of death in sickle cell disease in Jamaica. BM 1982;285:633-5.

2 Gray A, Anionwu EN, Davies SC, et al. Patterns of mortality in sickle cell disease in the United Kingdom. J Clin Pathol 1991;44:459-63.

3 Vichinsky EP, Styles LA, Colangelo LH, et al. Acute chest syndrome in sickle cell disease: clinical presentation and course. Blood 1997;89:1787-92.

4 Vichinsky EP, Neumayr LD, Earles AN, et al. Causes and outcomes of the acute chest syndrome in sickle cell disease. N Engl J Med 2000;342:1855-65.

5 Quinn CT, Buchanan GR. The acute chest syndrome of sickle cell disease. J Pediatr 1999;135:416-22.

6 Poncz M, Kane E, Gill FM. Acute chest syndrome in sickle cell disease: etiology and clinical correlates. J Pediatr 1985; 107:861-6.

7 Sprinkle RH, Cole T, Smith S, et al. Acute chest syndrome in children with sickle cell disease. A retrospective analysis of 100 hospitalized cases. Am J Pediatr Hematol Oncol 1986;8:105-10. 
8 Barrett-Conner E. Pneumonia and pulmonary infarction in sickle cell anaemia. JAMA 1973;224:997-1000

9 Oppenheimer EH, Esterly JR. Pulmonary changes in sickle cell disease. Am Rev Respir Dis 1971;103:858-9.

10 Agtmael MA, Cheng JD, Nossent HC. Acute chest syndrome in AfroCaribbean patients with sickle cell disease. Arch Intern Med 1994;154:557-61.
11 Gastro O, Brambilla AJ, Thorington B, et al. The acute chest syndrome in sickle cell disease-incidence and risk factors. The Cooperative Study of Sickle Cell Disease. Blood 1994;84:643-9.

12 Vinchinsky E, Styles L. Pulmonary complications. Hematol/Oncol Clin North Am 1996;10:1275-87.

13 Yale S H, Nagib N, Guthrie T. Acute chest syndrome in sickle cell disease. Postgrad Med 2000; 107:215-22.

\section{Clinical Evidence-Call for contributors}

Clinical Evidence is a regularly updated evidence based journal available worldwide both as a paper version and on the internet. Clinical Evidence needs to recruit a number of new contributors. Contributors are health care professionals or epidemiologists with experience in evidence based medicine and the ability to write in a concise and structured way.

\section{Currently, we are interested in finding contributors with an interest in} the following clinical areas:

Altitude sickness; Autism; Basal cell carcinoma; Breast feeding; Carbon monoxide poisoning; Cervical cancer; Cystic fibrosis; Ectopic pregnancy; Grief/bereavement; Halitosis; Hodgkins disease; Infectious mononucleosis (glandular fever); Kidney stones; Malignant melanoma (metastatic); Mesothelioma; Myeloma; Ovarian cyst; Pancreatitis (acute); Pancreatitis (chronic); Polymyalgia rheumatica; Post-partum haemorrhage; Pulmonary embolism; Recurrent miscarriage; Repetitive strain injury; Scoliosis; Seasonal affective disorder; Squint; Systemic lupus erythematosus; Testicular cancer; Varicocele; Viral meningitis; Vitiligo However, we are always looking for others, so do not let this list discourage you.

\section{Being a contributor involves:}

- Appraising the results of literature searches (performed by our Information Specialists) to identify high quality evidence for inclusion in the journal.

- Writing to a highly structured template (about 2000-3000 words), using evidence from selected studies, within 6-8 weeks of receiving the literature search results.

- Working with Clinical Evidence Editors to ensure that the text meets rigorous epidemiological and style standards.

- Updating the text every eight months to incorporate new evidence.

- Expanding the topic to include new questions once every 12-18 months.

If you would like to become a contributor for Clinical Evidence or require more information about what this involves please send your contact details and a copy of your CV, clearly stating the clinical area you are interested in, to Claire Folkes (cfolkes@bmigroup.com).

\section{Call for peer reviewers}

Clinical Evidence also needs to recruit a number of new peer reviewers specifically with an interest in the clinical areas stated above, and also others related to general practice. Peer reviewers are health care professionals or epidemiologists with experience in evidence based medicine. As a peer reviewer you would be asked for your views on the clinical relevance, validity, and accessibility of specific topics within the journal, and their usefulness to the intended audience (international generalists and health care professionals, possibly with limited statistical knowledge). Topics are usually $2000-3000$ words in length and we would ask you to review between 2-5 topics per year. The peer review process takes place throughout the year, and our turnaround time for each review is ideally 10-14 days.

If you are interested in becoming a peer reviewer for Clinical Evidence, please complete the peer review questionnaire at www.clinicalevidence.com or contact Claire Folkes(cfolkes@bmigroup.com). 